Emissions from Concentrated Animal Feeding. Environ Health Perspect. 2007 Feb; 115(2): P.303-307.

5. Ciganek M., Neca J. Chemical Characterization of Volatile Organic Compounds on Animal Farms. Veterinary medicine. 2008. 53 (12). P. 641-651.

6. Reiffenstein R.J., Hulbert W.C., Roth S.H. Toxicology of Hydrogen Sulfide. Ann. Rev. Pharmacol. Toxicol. 1992. Vol. 32. P.109-134.

7. Вознюк О.В., Картавцев О.М., Петрук Л.В., Шелюк А.І. Оцінка порогових рівнів запаху забруднюючих речовин, що надходять від стаціонарних джерел викиду // Тези доп. наук. конф., присвяченої Всесвітньому дню здоров'я. Східноєвропейський журнал громадського здоров'я. 2010. № 1. С. 69-70.

REFERENCES

1. SI "O.M. Marzieiev Institute of Hygiene and Medical Ecology, NAMS of Ukraine. Udoskonalennia hihiienichnykh vymoh do rozmishchennia tvarynnytskykh kompleksiv z suchasnymy tekhnolohiiamy vyrobnytstva : zvit pro naukovo-doslidnu robotu [Improvement of the Hygienic Requirements to the Siting of Cattle-Breeding Complexes with Modern Technologies of Production : Report on Scientificand-Research Work]. Kyiv ; 2011 : 21-28, 174-182, 201-208 (in Ukrainian).

2. van Harreveld A.Ph. Odor Regulation and the History of Odor Measurement in Europe. Barcelona ; 2005 : 54-60.

3. Turos O.I., Petrosian A.A. and Kartavtsev O.M. Identyfikatsiia nebezpeky vid zabrudnennia atmosfernoho povitria statsionarnymy dzherelamy [Identification of the Risk from Ambient Air Pollution by Stationary Sources]. Kyiv ; 2007 : 4 p. (Inform. lyst №211/IGME AMNU) (in Ukrainian).

4. Bunton B. and O'Shaughnessy P. Environ Health Perspect. 2007; 115 (2) : 303-307.

5. Ciganek M. and Neca J. Veterinary medicine. 2008 ; 53 (12) : 641-651.

6. Reiffenstein R.J., Hulbert W.C. and Roth S.H. Ann. Rev. Pharmacol. Toxicol. 1992 ; 32 : 109-134.

7. Vozniuk O.V., Kartavtsev O.M., Petruk L.V. and Sheliuk A.I. Skhidnoievropeiskyi zhurnal hromadskoho zdorovia. 2010 ; 1 : 69-70 (in Ukrainian).

Надійшла до редакції 10.05.2017

\section{HYGIENIC EVALUATION OF MODERN TECHNOLOGIES FOR HANDLING WITH SOLID DOMESTIC WASTE AND PROSPECTS FOR THEIR IMPLEMENTATION IN UKRAINE} Teteniova I.O.

ГІГЕННЧНА ОЦПККА СУЧАСНИХ ТЕХНОЛОГИЙ ПОВОДЖЕННЯ З ТВЕРДИМИ ПОБУТОВИМИ ВІДХОДАМИ ТА МОЖЛИВІСТЬ ВПРОВАДЖЕННЯ ЇХ В УКРАЇНП

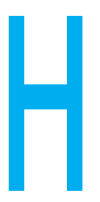

TETEHЬOBA I.O.

ДУ «Інститут громадського здоров'я ім. О.М. Марзєєва

НАМН України», м. Київ

УДК $614.777: 628.4$

Ключові слова: тверді побутові відходи, сміттєсортування, неутилізована частка твердих побутових відходів після сортування, ущільнення, біопрепарати. айбільш поширені в Україні та у дих побутових відходів (ТПВ) складування на полігонах та спалювання - мають великі негативні екологічні наслідки та впливають на умови проживання населення [1-6].

В останні роки в Україні почали розвиватися нові технології поводження з ТПВ, які донині не були досліджені з точки зору безпечності їх застосування для умов проживання населення у зонах впливу об'єктів захоронення.

Загальна схема поводження з ТПВ передбачає низку операцій: збирання, оброблення, світі методи видалення твер-

ГИГИЕНИЧЕСКАЯ ОЦЕНКА СОВРЕМЕННЫХ ТЕХНОЛОГИЙ

ОБРАЩЕНИЯ С ТВЕРДЫМИ БЫТОВЫМИ ОТХОДАМИ

И ПЕРСПЕКТИВЫ ИХ ВНЕДРЕНИЯ В УКРАИНЕ

Тетенева И.А.

ГУ «Институт общественного здоровья им. А.Н. Марзеева НАМН Украины", г. Киев

Цель работы: санитарно-гигиеническая оценка современных методов переработки и захоронения ТБО, перспективы их внедрения в Украине. Материалы и методы. Материал исследования - неутилизированный остаток ТБО после промышленной сортировки. Исследования влияния мусоросортировки на состав и свойства неутилизированной части ТБО были проведены нами в натурных условиях на мусоросортировочной станции ОАО "Гринко-центр" (г. Киев) по стандартизированным методикам. Тяжелые металлы определяли атомно-абсорбционным методом на спектрофотометре типа КАС-120.1.

Биологическая активность отходов определялась по показателю дегидрогеназная активность, которая определялась по модифицированной методике согласно Патенту Украины № 22364. Влияние биопрепаратов на ускорение разложения органических отходов оценивалось по динамике уменьшения массы ТБО и выделению фильтрата с течением времени

Результаты. В работе представлен анализ современных методов переработки и захоронения твердых бытовых отходов (ТБО).

Показано, что неутилизированный остаток ТБО после сортировки является более безопасным для захоронения. В составе ТБО снижается содержание тяжелых металлов и наоборот, регистрируется некоторое повышение содержания микроэлементов. В неутилизированной части ТБО после сортировки содержание тяжелых металлов (свинец, кадмий, никель, кобальт) в отличие от нативных ТБО не превышает их кларки и ПДК в почве. Предложены способы оптимизации обращения с неутилизированной частью ТБО после сортировки. Уплотнение смеси (10 частей отходов и 1 часть золошлаков) до $1 \mathrm{kг} / \mathrm{cm}^{3}$ приводит к минимизации процессов биологического разложения органических веществ. При применении ферментных (оксизин) и микробных препаратов (ЭМ-1) для обработки неутилизированной части ТБО после сортировки глубина разложения органических веществ в 1,5 (оксизин) 1,7(ЭМ-1) раза выше, чем при естественной деструкции.

Ключевые слова: твердые бытовые отходы (ТБО), уплотнение, мусоросортировка, неутилизированный остаток твердых бытовых отходов после сортировки, биопрепараты.

() Тетеньова I.O. СТАТТЯ, 2017. 
господарства України № 133 від 01.08.2011 р., роздільне збирання ТПВ впроваджується поетапно, зокрема на першому етапі - шляхом проведення експериментів 3 роздільного збирання ТПВ в окремих районах населеного пункту з використанням різних технологічних схем з метою визначення найбільш ефективної та прийнятної для даного населеного пункту.

У ряді міст України (Київ, видалення чи утилізацію ТПВ.

Сміттєсортування $є$ обов'язковим елементом будь-якої технології поводження з ТПВ. Розрізняють первинне сортування, або роздільний збір, яке здійснюється у місцях утворення сміття, та вторинне, або промислове сортування, яке проводиться у межах місць захоронення відходів або на спеціальних майданчиках.

В Україні роздільний збір $€$ обов'язковим елементом поводження 3 ТПВ (Закони України «Про відходи», «Про житлово-комунальні послуги», «Про благоустрій населених пунктів, «Про внесення змін до деяких законодавчих актів України у сфері поводження з відходами» від 21.01.2010 р., ДСанПіН утримання територій населених місць № 145-11). Сучасним законодавством України для впровадження роздільного збору затверджено методику роздільного збирання побутових відходів з визначенням технологічних схем та типів контейнерів та їх маркування (Методика роздільного збирання побутових відходів, затверджена наказом Міністерства регіонального розвитку, будівництва та житловокомунального господарства України № 133 від 01.08.2011), за нашої участі визначено гігієнічні вимоги до контейнерних майданчиків для роздільного збирання (Державні санітарні правила і норми утримання територій населених місць, затверджені наказом Міністерства охорони здоров'я України № 145 від 17.03.2011 р.).

Нині роздільне збирання ТПВ майже не впроваджується в Україні. Згідно з Методикою роздільного збирання побутових відходів, затвердженою наказом Міністерства регіонального розвитку, будівництва та житлово-комунального
Харків, Іллічівськ та ін.) було проведено експерименти 3 роздільного збору ТПВ $[7,8]$. Результати експериментів дозволили констатувати, що населення активно сортувало сміття, при цьому частка вторинної сировини сягала $70 \%$ [9] (у країнах Європи - до 92\%) [10]. Здебільшого роздільний збір ТПВ не призводив до утворення "чистих" фракцій вторинної сировини, придатних для прямої реалізації переробним підприємствам. У складі роздільно зібраних ТПВ неминуче були присутні звичайні "змішані" ТПВ, помилково складовані у контейнери для роздільного збору. Крім того, у процесі зберігання у відкритих контейнерах сухі відібрані фракції втрачали свою комерційну цінність під дією атмосферних опадів. Головним недоліком цієї системи була відсутність спеціального транспорту для перевезення вторинної сировини. В Україні не налагоджено систему роздільного вивозу окремих фракцій. Відібрані населенням ресурсоцінні фракції перемішували 3 несортованими відходами вивозили одним сміттєвозом на полігон.

Результати експериментів показали, що населення готове для впровадження роздільного збору, розроблено законодавчу базу для його застосування, проте реалізація цього процесу гальмується органами виконавчої влади у сфері поводження з відходами у зв'язку з відсутністю спеціального транспорту для транспортування відсортованої вторинної сировини на підприємства з її переробки.

Промислове сміттєсортування почало впроваджуватися в Україні понад 10 років тому. За даними Міністерства регіонального розвитку, будівницт- ва та житлово-комунального господарства України, у 15 населених пунктах працюють сміттєсортувальні лінії [11].

Суттєвою невирішеною проблемою при застосуванні промислового сміттєсортування $€$ питання безпечного поводження 3 неутилізованою часткою ТПВ, яка нині без обробки захоронюється на сміттєзвалищах та полігонах.

Мета роботи: дати санітарно-гігієнічну оцінку сучасних методів переробки та захоронення ТПВ та можливості їх запровадження в Україні.

Матеріали та методи. Матеріал дослідження - ТПВ та неутилізована частка ТПВ після промислового сортування. Дослідження щодо впливу сміттєсортування за складом і властивістю неутилізованої частки ТПВ були проведені нами у натурних умовах на сміттєсортувальній станції ВАТ „Грінко-центр", м. Київ. Дослідження виконано за стандартизованими методиками. Важкі метали визначали атомно-абсорбційним методом на спектрофотометрі типу KAC-120.1 (ЦІНАО).

Біологічна активність відходів визначалася за показником дегідрогеназна активність, яка визначалася за модифікованою методикою згідно 3 Патентом України № 22364.

Вплив обробки ТПВ біопрепаратами на прискорення розкладання органічних відходів оцінювався за динамікою зменшення маси ТПВ та виділення фільтрату з плином часу.

Результати дослідження та ïx обговорення. У процесі сміттесортування частково вилучаються полімерні вироби, скло, папір та картон. У неутилізованій частині після сортування відзначається мінімальний вміст металобрухту та брухту скла. Неутилізована частка ТПВ після сортування складається 3 харчових відходів, дрібних фракцій (папір, картон, скло, змет, листя тощо) та фракцій, які нині не мають комерційного збуту (невеликі поліетиленові пакети після харчових продуктів, деякі види пластику тощо)

У процесі сміттєсортування щільність неутилізованої частки відходів збільшується з 210-

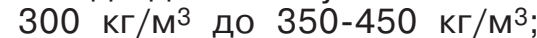
вологість - на 10-15\%, частка 
HYGIENIC EVALUATION OF MODERN TECHNOLOGIES FOR HANDLING WITH SOLID DOMESTIC WASTE AND PROSPECTS FOR THEIR IMPLEMENTATION IN UKRAINE Teteniova I.O.

SI "O.M. Marzeiev Institute for Public Health, NAMSU", Kyiv

Objective. We presented a sanitary-and-hygienic assessment of modern methods for recycling and disposal of solid domestic waste (SDW) and prospects of their implementation in Ukraine.

Materials and methods. The unutilized residue of SDW after industrial sorting was the material of the study. Investigations of the influence of waste sorting on the composition and properties of the unutilized residue of solid waste were carried out by us under field condition at the garbage sorting station of JSC

"Greenco-Center", Kyiv. The study was performed according to the standard procedures. Heavy metals were determined by the atomic absorption method with the help of spectrophotometer of CAS-120.1type. The biological activity of the waste was determined by the index of dehydrogenase activity. The dehydrogenase activity of the waste was determined by the modified methodology in accordance with the Patent of Ukraine № 22364. Influence of biological preparations on the acceleration of the decomposition of organic waste was evaluated by the dynamics of the reduction of SDW weight and the release of filtrate in time.

Results. There is an analysis of modern methods for recycling and disposal of SDW in the work. It is shown that unutilized part of SDW after sorting is safer for disposal. The content of heavy metals decreases in the content of unutilized SDW after sorting and, vice versa, a certain increase of microelements' content is registered in it. After sorting, in the unutilized part of SDW a content of heavy metals (lead, cadmium, nickel, cobalt) doesn't exceed their clarkes and MAC in soil in contrast to native SDW. The methods for the optimization of handling with the unutilized part of SDW after sorting are proposed. Compaction of the mixture (10 parts of waste to 1 part of ash) up to $1 \mathrm{~kg} / \mathrm{cm}^{3}$ causes a minimization of biological decomposition of the organic substances. When enzyme (oxyzine) and microbial preparations (EM-1) are used for the recycling of SDW after sorting, the decomposition's depth of organic substances is greater by 1.5 (oxyzine) - 1.7(EM-1) fold than under natural destruction.

Keywords: solid domestic waste (SDW), sorting of waste, unutilized residue of solid domestic waste after sorting, compaction, biopreparations. органічних відходів зростає 3 50-60\% до 65-80\% через переважне вилучення при сортуванні полімерних матеріалів, і картону. У процесі сміттєсортування у складі ТПВ зменшується вміст важких металів (свинець, кобальт, нікель, кадмій), реєструється деяке збільшення вмісту цинку, міді та марганцю, що зумовлене збільшенням частки харчових та рослинних відходів у структурі ТПВ. у неутилізованій частині ТПВ вміст важких металів (свинець, кадмій, нікель, кобальт), на відміну від нативних ТПВ, не перевищує їхні кларки (природний фон) та ГДК у ґрунті. Перевищення кларків у неутилізованій частині ТПВ після сортування зареєстровано для міді (до 8 разів), цинку (до 2 разів); ГДК - для міді (до 3 ГДК) та цинку (до 1,2 ГДК) (табл. 1).

3 гігієнічної точки зору сміттєсортування позитивно впливає на якість ТПВ, що пов'язано не тільки зі зменшенням кількості відходів, а й зі змінами морфологічного складу неутилізованої частини ТПВ на більш сприятливий для подальшої обробки та захоронення (виключення із ТПВ компонентів, які зменшують щільність ТПВ, мають значний термін розкладання у ґрунті, містять найбільш небезпечні для здоров'я людини хімічні речовини тощо).

Після сміттєсортування залишається неутилізованою частка, безпечне поводження 3 якою $€$ невирішеною проблемою в Україні. Такі відходи малопридатні для термічної обробки за рахунок високої вологості, вони малопридатні для компостування через значний вміст речовин, що не піддаються біологічному розкладанню.

Для оптимізації процесів захоронення неутилізованої частини ТПВ після сортування було проведено експериментальні дослідження впливу ущільнення залишкової частини твердих побутових відходів після сортування на їх біологічну активність та можливості застосування ферментних та мікробних препаратів для

обробки залишкової частки ТПВ після сортування.

Модельні суміші мали такий склад: папір та картон - 28\%; харчові відходи - 51\%; поліетилен - 5\%; вуличний змет, листя - 10\%; полімерні матеріали 5\%; текстильні матеріали - 1\%.

Біологічна активність ТПВ визначалась за показником дегідрогеназна активність.

у неущільненій неутилізованій частині ТПВ після сортування спостерігається висока дегідрогеназна активність, яка свідчить про інтенсивні біологічні процеси, що відбуваються у ТПВ (рис. 1). Глибоке пресування суттєво зменшує активність біологічних процесів у

Таблиця 1

Результати фізико-хімічних досліджень ТПВ до і після сортування, $(n=12)$

\begin{tabular}{|c|c|c|c|c|}
\hline Показник & $\begin{array}{c}\text { Кларк } \\
\text { (за О.П. Ви- } \\
\text { ноградовим) }\end{array}$ & $\begin{array}{c}\text { ГДК у } \\
\text { грунті, } \\
\text { мГ/кг }\end{array}$ & $\begin{array}{c}\text { Несортовані } \\
\text { ТПВ, } \\
\text { M } \pm m\end{array}$ & 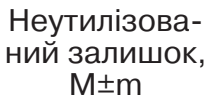 \\
\hline Щільність, кг/м³ & & & $273,56 \pm 86,09$ & $392,67 \pm 54,33$ \\
\hline $\mathrm{pH}$ & & & $5,85 \pm 0,32$ & $5,63 \pm 0,38$ \\
\hline $\begin{array}{l}\text { Масова частка } \\
\text { вологи, \% }\end{array}$ & & & $37,45 \pm 6,34$ & $51,69 \pm 12,07$ \\
\hline $\begin{array}{l}\text { Вміст мінеральних } \\
\text { речовин, \% }\end{array}$ & & & $42,29 \pm 4,47$ & $36,18 \pm 7,05$ \\
\hline $\begin{array}{l}\text { Вміст органічних } \\
\text { речовин, \% }\end{array}$ & & & $57,96 \pm 4,15$ & $64,06 \pm 7,45$ \\
\hline Свинець, мг/кг & 10 & 32 & $0,73 \pm 0,32$ & $0,068 \pm 0,02$ \\
\hline Мідь, мг/кг & 20 & 55 & $62,57 \pm 35,06$ & $72,42 \pm 31,09$ \\
\hline Цинк, мг/кг & 50 & 100 & $73,743 \pm 23,43$ & $93,41 \pm 20,69$ \\
\hline Кобальт, мг/кг & 8 & 5 & $17,80 \pm 7,51$ & $6,01 \pm 3,11$ \\
\hline Нікель, мг/кг & 40 & 85 & $32,57 \pm 7,94$ & $15,17 \pm 2,47$ \\
\hline Марганець, мг/кг & 850 & - & $50,35 \pm 14,13$ & $58,92 \pm 12,99$ \\
\hline Кадмій, мг/кг & 0,5 & & $0,18 \pm 0,08$ & $0,60 \pm 0,22$ \\
\hline
\end{tabular}


ТПВ. Кратність перевищення дегідрогеназної активності у неущільнених ТПВ порівняно 3

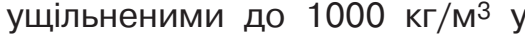
середньому становить 2 рази. Інтенсивність біологічних процесів у неутилізованій частині ТПВ після сортування 3 ущільненням до 1000 кг/м³ зменшується переважно за рахунок зниження показників вологості (від 65\% до 35\%) та зменшення доступу кисню у процесі окислення органічних речовин.

Пресування відходів до

\section{Вплив ущільнення на біологічну активність залишкової частки ТПВ після сортування}

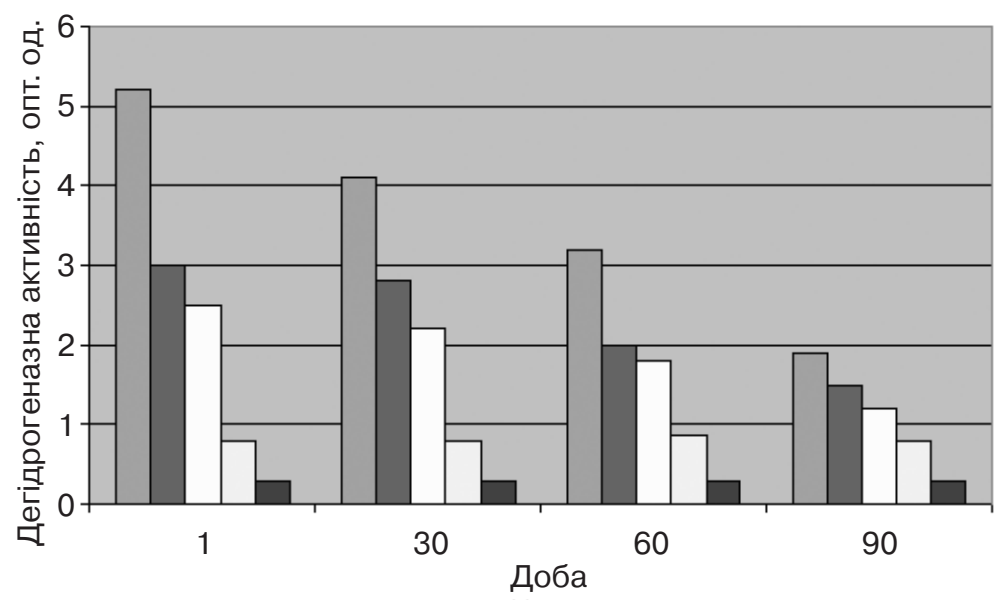

\begin{tabular}{|c|}
\hline 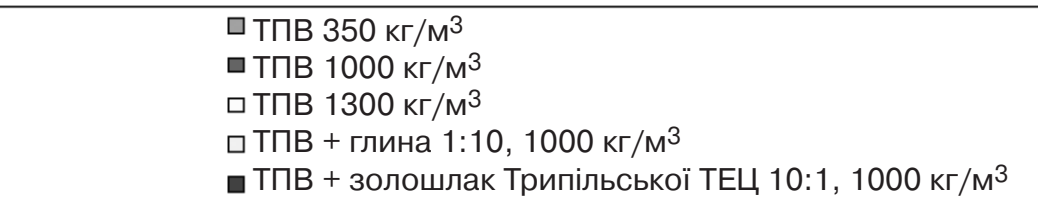 \\
\hline
\end{tabular}

Динаміка зміни ваги залишкової частини ТПВ після сортування у лабораторному експерименті з впливом ферментів (оксизин) та ефективних мікроорганізмів (у розрахунку на 1 кг ТПВ)

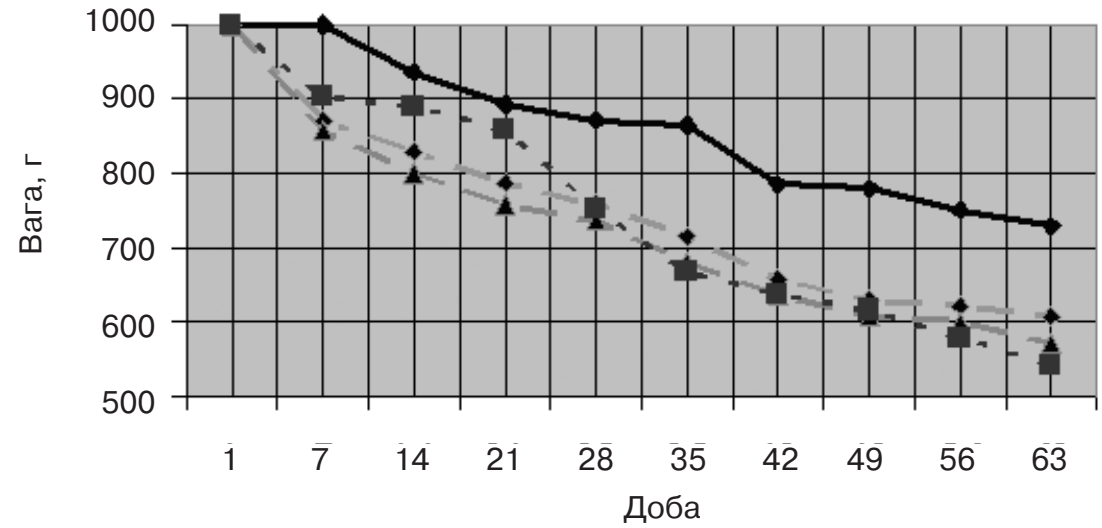

$$
\begin{array}{ll}
\longrightarrow \text { Контроль } & \bullet-+0,02 \text { мг/кг оксизину } \\
-\boldsymbol{\star}-+0,04 \text { мг/кг оксизину } & -\boldsymbol{-}+0,02 \text { мл/кг ЕМ-1 }
\end{array}
$$

суміші до 1000 кг/м³ суттєво зменшує дегідрогеназну активність (до 0,8 од. опт. щільності), проте не призводить до пригнічення ферментативних процесів за рахунок малої втрати рідини у відходах.

Використання золошлакової суміші (відходів Трипільської ТЕЦ) в якості зв'язуючого матеріалу призводить до значного зменшення вологи та зрушення $\mathrm{pH}$ суміші у нейтральний бік. Ущільнення суміші (10 частин відходів та 1 частина золошлаку) до 1000 кг/м³ призводить до зменшення рівня дегідрогеназної активності до найменших рівнів, що свідчить про мінімізацію процесів біологічного розкладання органічних речовин.

Застосування технології ущільнення залишкової частини ТПВ після сміттєсортування з додатковим внесенням copбуючої компоненти (золошлакові суміші) при захороненні ТПВ докорінно покращить санітарно-гігієнічну ситуацію на полігонах: гальмуються процеси гниття, припиняються аеробні процеси, практично не відбувається виділення токсичного і пожежонебезпечного біогазу. Брикет за достатньої щільності не акумулює у собі атмосферні опади. Як наслідок, практично виключаються характерні для утилізації ТПВ санітарно-гігієнічні проблеми: забруднення підземних вод фільтратом з тіла полігону; пожежі від загоряння біогазу; поширення інфекцій тваринами, птахами; розлітання легкої фракції сміття прилеглими територіями тощо.

Нами були проведені експериментальні дослідження щодо можливості застосування пробіотиків (ферментів класу оксигеназ - оксизин та мікробного препарату EM-1) для обробки залишкової частини твердих побутових відходів після сортування.

Ферментним препаратом слугував оксизин (синтезований в Україні аналог препарату американського походження класу оксидаз Perma-zyme), в якості мікробного - ефективні мікроорганізми (EM) на основі концентрату EM-1, які розповсюджуються корпорацією EMRO (Японія) через представництво в Україні (м. Кропивницький).

Вплив обробки ТПВ біопрепаратами на прискорення роз- 
кладання органічних відходів оцінювався за динамікою зменшення маси ТПВ з плином часу (рис. 2). Процес переробки відходів також контролювався за щоденною динамікою виділення фільтрату (рис. 3).

В усіх зразках відзначається поступове зниження ваги з плином часу, що зумовлене переважно втратою вологи за рахунок утворення фільтрату та видалення його у дренаж, а також випаровуванням води 3 поверхні ТПВ.

В усіх дослідних пробах втрата ваги значно більша, ніж у контрольній пробі, що свідчить про інтенсифікацію процесу біорозкладання органічних речовин під дією пробіотиків. Найбільша втрата ваги за 63 доби спостереження (457 г/кг ТПВ) відзначалася при додаванні до сортованих відходів препарату EM-1, що майже вдвічі більше, ніж за природної деструкції (271 г/кг). Втрата ваги при додаванні ферментного препарату дещо менша 429 г/кг (кратність перевищення порівняно з контролем - 1,6) при додаванні оксизину у дозі 0,04 мл/кг та 393 г/кг у дозі 0,02 мл/кг (порівняно з контролем - в 1,45 рази).

Динаміка утворення фільтрату $€$ показником інтенсивності процесів біологічного розкладання органічних речовин, оскільки у лабораторних умовах фільтрат виділяється лише у результаті біохімічних процесів, які супроводжуються утворенням води за анаеробного розкладання їхньої органічної складової (рис. 3).

У контрольному зразку виділення фільтрату починається на другому тижні у максимальних кількостях, далі відбувається поступове зниження і припинення на шостому тижні. При застосуванні ефективних мікроорганізмів процес виділення фільтрату має хвилеподібний характер і продовжується найдовше - до 9 тижнів. Інтенсивне виділення фільтрату при застосуванні ферментного препарату продовжується перші чотири тижні при внесенні препарату у дозі 0,02 мл/кг та перші три тижні - 0,04 мл/кг. Далі відбувається зниження виділення фільтрату і припинення виділення його відповідно на 8-му та 7-му тижнях від початку експерименту.
При застосуванні ферментних і мікробних препаратів процеси розкладання органічних речовин відбуваються більш інтенсивно і повно, ніж природним шляхом, про що свідчить кількість виділеного фільтрату. Найбільш повно процеси розкладання органічних речовин здійснюються при застосуванні мікробних препаратів. Загальна кількість фільтрату, утвореного при застосуванні препарату EM-1, у 3,3 рази перевищує контроль, при застосуванні оксизину у дозі 0,02 мл/кг - у 2,4 рази. Доцільно застосовувати оптимальну мінімальну дозу препарату, оскільки збільшення дози ферменту вдвічі лише незначним чином підвищує інтенсивність процесу окислення органічних речовин.

Втрата ваги у контрольних і дослідних зразках продовжується і після закінчення утворення фільтрату. У перші чотири тижні втрата ваги зумовлена переважно виділенням фільтрату, у більш віддалені терміни спостереження - іншими факторами (випаровування тощо). Дія ферментних препаратів порівняно $з$ мікробними більш швидка у часі, а мікробних препаратів - більш глибока. За один вегетаційний період відбувається переробка усіх легкоокислюваних органічних речовин, що дозволяє зменшити об'єм ТПВ на полігонах та подовжити строк його експлуатації майже вдвічі.

\section{\begin{tabular}{l} 
Рисунок 3 \\
\hline у
\end{tabular} утворення фільтрату у лабораторному експерименті з впливом ферментів (оксизин) та ефективних мікроорганізмів}
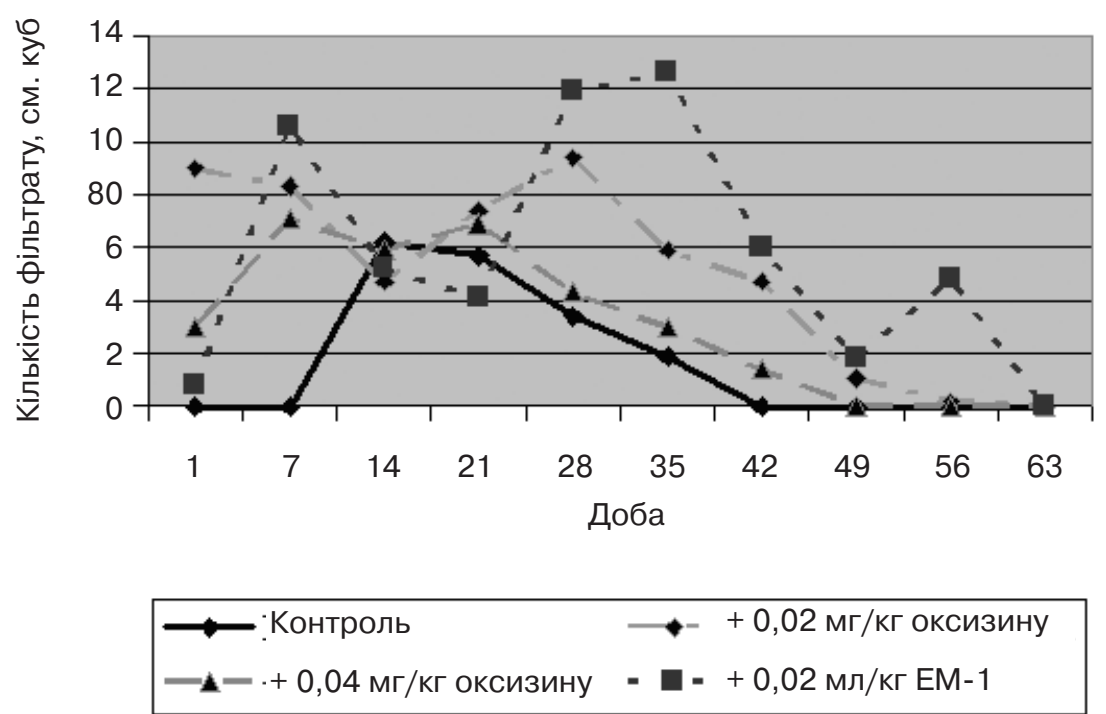
Dumpsite, Freetown, Sierra Leone. Journal of Environmental Protection. 2013. № 4. P. 665 670.

3. Бородай Г.И. Пособие по мониторингу полигонов твердых бытовых отходов. Донецк : Тасис, 2004. 293 с.

4. Архипова Г.І., Галушка Ю.О. Вплив звалищ побутових відходів на здоров'я людей. Вісник НАУ. 2009. № 3. C. 217-219.

5. Юфит С.С. Мусоросжиганя вмісту цинку, міді та марганцю, що зумовлене збільшенням частки харчових та рослинних відходів у структурі ТПВ. Такі відходи є безпечнішими для захоронення.

3. Для стабілізації біологічних процесів у неутилізованій частині ТПВ після сортування запропоноване ущільнення залишкової частини ТПВ після сміттєсортування 3 додатковим внесенням сорбуючої компоненти (золошлакові суміші), що призводить до покращання стану навколишнього середовища за рахунок зменшення викидів в атмосферне повітря речовин з неприємним запахом, зменшується негативний вплив на поверхневі та підземні води, майже відсутнє засмічення прилеглої до полігону території.

4. При застосуванні пробіотиків для обробки неутилізованої частини ТПВ після сортування процеси розкладання органічних речовин відбуваються інтенсивніше і більш повно, ніж природним шляхом. Глибина переробки органічних речовин при застосуванні пробіотиків в 1,5 (оксизин) - 1,7 (EM-1) рази вища, ніж за природної деструкції. За 1-1,5 місяці у теплий період та 3 місяці у прохолодний період року відбувається переробка усіх легкоокислюваних органічних речовин, що призводить до зменшення обсягів накопичених ТПВ майже вдвічі, їх кращого самоущільнення.

ЛІТЕРАТУРА

1. Матвеев Ю.Б., Пухнюк А.Ю. Полигоны бытовых отходов: ситуация и перспективы. Твердые бытовые отходы. 2013. № 6. С. 37-42.

2. Foday Pinka Sankoh, Xiangbin Yan, Quangyen Tran. Environmental and Health Impact of Solid Waste Disposal in Developing Cities: A Case Study of Granville Brook тельные заводы - опасность для России. Твердые бытовые отходы. 2009. № 3. С. 50-55.

6. Лапицкий В.Н., Борисовская Е.А., Гончаренко В.И. Экологические последствия термической переработки твердых бытовых отходов. Техногенно-екологічна безпека та цивільний захист. 2010. Вип. 1. С. 80-83.

7. Бардаков В.А. Эффективность селективного сбора ТБО. Режим доступа:

http://eprints. kname.edu.ua/38 859/1/66-69. pdf.

8. Маковецкая Ю.М.

Региональные особенности сферы обращения с отходами. Отходы - вторичные ресурсы: управление, экономика, организация: коллективная монографія: в 2 т. Сумы : Сумской гос. ун-т, 2013. T. 2. C. 49-70.

9. Довга Т.М. Основні тенденції та закономірності утворення і переробки твердих побутових відходів в Україні. Ефективна економіка. 2012. № 10. Режим доступу: http://www.economy.nayka.com .ua/?op=1\&z=1491.

10. Управление отходами: зарубежный опыт. Режим доступа : http:// ecoalliance.com.ua/bbloteka/ statt-po-vdxodam/upravlenieotxodami-zarubezhnyij-opyit.

11. Мінрегіон продовжує формувати та реалізовувати державну політику у сфері поводження з побутовими відходами. Режим доступу: http://www.kmu.gov.ua/control/uk/publish/printable_article?art id=249064633

\section{REFERENCES}

1. Matveev Yu.B. and Pukhniuk A.Yu. Tviordye bytovye otkhody. $2013 ; 6$ : 37-42 (in Russian).

2. Foday Pinka Sankoh, Xiangbin Yan and Quangyen Tran. Journal of Environmental Protection. 2013 ; 4 : 665-670.
3. Boroday G.I. Posobie po monitoring poligonov tverdykh bytovykh otkhodov [Manual on the Monitoring of the Solid Household Waste Polygons]. Donezk : Tasis ; 2004 : 293 p. (in Russian)

4. Arkhipova G.I. and Halushka Yu.O. Visnyk NAU. 2009 ; 3 : 217-219 (in Ukrainian).

5. Yufit C.C. Tviordye bytovye otkhody. 2009 ; 3 : 50-55 (in Russian).

6. LapitskiyV.N., Borisovskaia E.A. and Goncharenko V.I. Ekologicheskie posledstviia termicheskoi pererabotki tverdykh bytovykh otkhodov [ Ecological Consequences of Thermal Recycling of Solid Household Waste]. In : Tekhnohenno-ekolohichna bezpeka ta tsyvilnyi zakhyst [Technogenic-andEcological Safety and Civil Protection]. $2010 ; 1: 80-83$ (in Russian).

7. BardakovV.A. Effektivnost selektivnogo sbora TBO [Efficiency of solid waste selective collection]. URL: http://eprints. kname.edu.ua/38 859/1/66-69.pdf (in Russian).

8. Makovetskaia Yu.M.

Regionalnye osobennosti sfery obrashcheniia s otkhodami [Regional Features of Handling with Waste]. In : Otkhody vtorichnye resursy: upravlenie, ekonomika, organizatsiia : kollektivnaia monografiia [Waste - Secondary Resources: Management, Economy, Organization: Collective Monograph]. Sumy ; 2013 ; 2 : 49-70 (in Russian).

9. Dovha T.M. Efektyvna ekonomika. $2012 ; 10$. URL :

http://www.economy.nayka.com. ua/?op=1\&z=1491 (in Ukrainian).

10. Upravlenie otkhodamy: zarubezhnyi opyt [Waste Management: Foreign

Experience]. URL : http://ecoalliance.com.ua/bbloteka/stattpo-vdxodam/upravlenie-otxodami-zarubezhnyij-opyit

(in Russian).

11. Ministerstvo rehionalnoho rozvytku prodovzhuie formuvaty ta realizovuvaty derzhavnu polityku u sferi povodzhennia z pobutovymy vidkhodamy [Ministry of Regional Development Continues to Form and Realize the State Policy in the Sphere of the Handling of Household Waste]. URL http://www. kmu.gov.ua/ control/uk/publish/printable arti cle?art id=249064633 (in Ukrainian).

Надійшла до редакції 12.04.2017 